Corresponding Author:

Suhadianto

suhadianto.1801139@students. um.ac.id

Published: 5 January 2021

Publishing services provided by Knowledge E

(c) Suhadianto et al. This article is distributed under the terms of the Creative Commons

Attribution License, which permits unrestricted use and redistribution provided that the original author and source are credited

Selection and Peer-review under the responsibility of the ICoPsy Conference Committee.

\section{Stop Academic Procrastination During Covid 19: Academic Procrastination Reduces Subjective Well-Being}

\author{
Suhadianto ${ }^{1,2}$, Isrida Yul Arifiana ${ }^{1,2}$, Hetti Rahmawati ${ }^{1}$, Fattah Hanurawan ${ }^{1}$, and \\ Nur Eva ${ }^{1}$ \\ ${ }^{1}$ Faculty of Psychology Education, Universitas Negeri Malang, Malang, Indonesia \\ ${ }^{2}$ Faculty of Psychology, Universitas 17 Agustus 1945 Surabaya, Surabaya, Indonesia
}

\section{Abstract}

Happiness is the life goal of everyone, including students. But in fact, some student behavior is not in line with the effort to get happiness. Academic Procrastination is one of them. The Covid-19 pandemic, which requires learning to be carried out online, appears to have increased academic procrastination, although there is no definite data about it. This study aims to determine the impact of academic procrastination on Subjective Well-Being. The design of this research is literature review. Researchers conducted a literature search regarding the academic procrastination and subjective well-being through Google Scholar and ScienceDirect. Hermeneutic techniques are used to analyze the literature according to the research objectives. The literature review results show that academic procrastination reduces Subjective Well-Being. The results of this literature review can be a warning to students not to do academic procrastination.

Keywords: Academic procrastination; Subjective well-being; Academic Procrastination During Covid-19

\section{Introduction}

Happiness is everyone's hope. Therefore, happiness has a very important meaning for every individual, regardless of social status, age, and Education (Argyle, 2001). Whether children or adults, everyone wants happiness, including students. However, the facts show that not all student behavior is in line with efforts to obtain happiness. Academic procrastination is one of them. Research states that as many as $70 \%$ of students postpone regularly (Klingsieck, 2013). Research on Indonesian students also shows $78.5 \%$ of students do academic delays (Huda, 2015). This data was obtained long before the 2019 Coronavirus (Covid-19) pandemic occurred.

On January 30, 2020, the World Health Organization (WHO) has designated Covid-19 as the Public Health Emergency of International Concern (PHEIC) (WHO, 2020). After 
2020). The existence of positive cases of Covid-19 in Indonesia then affected various sectors, such as the economy, social tourism, and education. The Minister of Education and Culture of the Republic of Indonesia officially through Circular Number 4 of 2020 has stipulated that the teaching and learning process during Covid-19 is carried out at home through online or distance learning.

Learning activities carried out online cause students to be less able to understand the material provided by the lecturer, learning feels boring and can increase anxiety. The anxiety experienced by students regarding lessons during the Covid-19 pandemic can lead to academic procrastination behavior (Jia, Jiang, \& Lin, 2020). The results of researchers' observations on Indonesian students showed an increase in academic procrastination behavior. Although there are no exact figures on that.

Increased academic procrastination during the Covid-19 pandemic could have affected Subjective Well-Being. To answer this allegation, it is necessary to conduct a literature review in order to understand the concept of Subjective Well-Being and what factors can influence subjective well-being.

The study of happiness is slow to develop. Although it is very clear that the purpose of human life is to achieve happiness. The happiness that humans expect is not only related to pleasure, but happiness includes physical, psychological, social, and emotional aspects (Froh, Bono, \& Emmons, 2010).

Then how to see the happiness that is abstract. Happiness can be measured using the scale Subjective Well-Being (SWB) (Diener, Tay, \& Oishi, 2013). Empirical studies on happiness or better known as SWB only began in the first half of the 20th century and were not so clear until the late 1970s. However, when psychology and other social sciences are starting to be interested in researching SWB, thousands of studies on SWB have been carried out in the last two decades(Pavot \& Diener, 2011)

The spirit of psychology in studying SWB is proven by the emergence of positive psychology. The emergence of positive psychology has changed the direction of research in psychology, which initially only focused on the negative side or disorders suffered by human (Myers, 2004). Now psychological research has begun to talk a lot about happiness (Peterson \& Seligman, 2004).

SWB as an abstract psychological construct, in the end, raises debate among experts in explaining what factors can influence SWB. There are two very strong theories in explaining this problem. First, the theory top-down assumes that the overall feel of the SBW individual is closely related to individual evaluative assessments of various life domains and is related to continuous life experiences, so according to this theory SBW is built from the bottom up (life events form SWB). The second theory top-down assumes 
that there are factors that underlie individuals in assessing their life experiences, these factors are personality. This means that personality forms SWB (Pavot \& Diener, 2011).

Based on the argument, that SWB is not only influenced by personality but can also be influenced by specific events in a person's life. This literature review aims to find answers to the question of whether academic procrastination which is mostly done by students can also affect SWB ?. This literature review is important so that students have a picture of the negative impact of academic procrastination. Furthermore, this literature review is expected to be part of an effort to prevent the development of academic procrastination in students, especially in the COVID-19 pandemic situation where learning is carried out online so that lecturers do not have strong control over student academic discipline.

\section{Literature Review}

\subsection{Subjective Well-Being Construction}

Among several conceptions of SWB, the most widely used concepts of welfare are psychological well-being (Ryff, 1989); (Ryff \& Keyes, 1995) and subjective well-being (Diener, 1984). PWB and SWB have different conceptions, although they ultimately complement each other. PWB is based on the tradition eudaimonic (the real self). PWB is considered to represent feelings of well-being that come from personal growth, autonomy, environmental control, positive interpersonal relationships, and life goals (Ryff, 1989). SWB lies more in the traditional hedonic, with the experience of positive feelings and life satisfaction as its main focus (Pavot \& Diener, 2011).

The construction of Psychological well-being (Ryff, 1989) is indeed different from the SWB Diener Concept (Diener, 1984). PWB has six dimensions, namely, self-acceptance, namely having a positive view of oneself (accepting the past, strengths, and weaknesses), positive relationships with others (positive relations with others), namely having a warm and trusting relationship and able to love others, autonomy(autonomy)that is capable of taking decisions, act independently, and can be regulation of behavior from within based on personal standards, mastery of the environment(environmental mastery/which is able to regulate the lives of themselves and the environment, was able to find, select, and make the environment To be in accordance with one's own needs and capacities, personal growth individual continues to build self-potential to grow and develop, and apurpose in life, which is to have a direction, purpose, and meaning in life. 
Unlike the PWB construction which includes six dimensions, the SWB construction consists of three main components (tripartite theory), including Positive affect (PA), Negative Affect (NA), and Life Satisfaction. The affective component of PA and NA reflects the ongoing evaluation of emotions and mood states which are both independent, while the life satisfaction component is an evaluation or cognitive assessment, made by the individual, of the quality of his life state and of life as a whole. The SWB construction is still general in nature, for more specific purposes. For example, an assessment of satisfaction with a specific domain, such as housing, employment, income, correlation, and marriage, can provide a more complex description of an individual's experience of SWB (Pavot \& Diener, 2011).

Although the PWB and SWB constructs are significantly different, they actually support each other. Evidence of a link between the PWB and SWB construction can be proven through research by (Goodman, Disabato, Kashdan, \& Kauffman, 2018). This study found a very strong correlation (0.85) between the SWB Diener model (Diener, 1984) and the PWB model PERMA (Positive emotion, Engagement, Relationship, Meaning, Accomplishments) which is newer than (Seligman, 2018).

\subsection{Factors Affecting Subjective Well-Being}

Until now, it is still a debate among experts regarding the causes of SWB. The SBW theory model can be grouped into two categories, namely the bottom-up theory and theory top-down. The theory bottom-up assumes that the overall feel of the SBW individual is closely related to individual evaluative assessments of various life domains and are related to continuous life experiences, so according to this theory, SBW is built from the bottom up, meaning that life events form SWB. Conversely, the theory top-down assumes that there are factors that underlie individuals in assessing their life experiences, these factors are personalitas (Pavot \& Diener, 2011).

The long debate regarding models bottom-up and top-down has resulted in many studies that prove that special events or incidents in an individual's life can influence SWB. However, studies on the correlation between personality and SWB also provide strong evidence of the influence between extraversion and neuroticism on SWB. These results indicate that both models have an influence on SBW, so a comprehensive model is needed to explain SWB. In the end, it can be concluded that the correlation between personality and SWB is highly mediated by the affective component (Pavot \& Diener, 2011). 
Although events in life have been shown to have an influence on SWB, personality factors are seen to have a very important role, both in terms of direct (top-down) or indirect (the role of personality in understanding life events). In addition, individual difference factors also greatly affect an individual's ability to adapt to a situation (Lucas \& Diener, 2015).

According to the theory of hedonic treadmill which is based on the theory of adaptation levels, life events and changes in life conditions may have an initial impact on SWB, but each individual is fast. accustomed to and adapt to a new environment or situation so that it will return to a neutral hedonic point. This means that a life event does not have a long-term impact on SWB, only events in the last two months that affect SWB. Reinforce thetheory hedonic treadmill. According to the Set Point Theory (SPT), adaptations to life events and changes do occur, after which the individual will return to the level set-point SWB, which is largely influenced by the temperament characteristics of extraversion and neuroticism. According to SPT, life events have only a small impact on SWB (Pavot \& Diener, 2011).

Other evidence regarding the influence of personality on SBW can be seen from individual differences in adaptation. Longitudinal studies of adaptation to major life events such as marriage found that some individuals adapt quickly while others are slow. These differences can be caused by the ability to deal with stress, and these differences, in turn, are related to personality. Individuals with high levels of neuroticism tend to use ineffective coping strategies that slow down the adaptation process (Lucas \& Diener, 2015).

Although the opinions of (Pavot \& Diener, 2011) and (Lucas \& Diener, 2015) emphasize the importance of the influence of personality on SWB. Recent studies seem not only to support thetheory top-down but also that many recent studies support thetheory bottom-up. The following are some of the latest studies related to the causes of SWB.

Several findings support thetheory top-down: 1) Research (Ardelt \& Jeste, 2018) reported a correlation between wisdom and SWB at the age of 80 years. The results also show that opennessto experiencesin early adulthood can predict wisdom 60 years later; 2) research by (Aghababaei, 2018) found a correlation between gratitude and the Big Five factors of personality with SWB; 3) research by (Ruch, Wagner, \& Heintz, 2018) found a correlation between the PEN (psychoticism, extraversion, neuroticism) model of personality and the choice of comic style, then comic style has a correlation with SWB; 4) research by (Liu, Peng, Zeng, Zhao, \& Zhang, 2019) found a correlation between authoritarian personality was also known to have a positive correlation with SWB by involving cultural context as a moderating variable; 5) (Prastuti, 2019) study 
found a correlation between emotion regulation and mindfulness with SWB mediated by gratitude; 6) Research (Galiani, Gertler, \& Undurraga, 2018) show that an unpleasant incident such as getting a decent housing program from the government, only causes an increase in SWB for 16 months, after which individual SWB tends to experience a $20 \%$ decrease every month.

Several findings support thetheory bottom-up: 1) Research by (Lampropoulou, 2018), for example, found a similar correlation between personality, family, and school factors with SWB; 2) Research by (Mogilner, Whillans, \& Norton, 2018) found a correlation between time and money and SWB; 3) Research (De Neve et al., 2018) found that a country's negative economic growth has a higher impact on SWB than positive information about a country's economic growth. Negative information about the country's economic growth has a longer negative impact on SWB; 4) research by (Kushlev, Heintzelman, Oishi, \& Diener, 2018) involving a total of 243,075 research subjects and drawn from 166 countries showed a negative correlation between social time and SWB. According to the results of this study, socializing 2.5 hours a day in the USA did not increase SWB. This means that the cultural context actually has an influence on SWB because research (Liu et al., 2019) found a positive correlation between authoritarian personality and SWB involving cultural context as a moderating variable; 5 ) research by (Ningtyas, Tentama, \& Situmorang, 2018) for the elderly in Indonesia also get a picture that the elderly SWB is very much influenced by social support.

Based on these recent studies, the author intends to conduct a literature study, whether the academic procrastination that is usually carried out by students or students in schools will also affect SWB.

\subsection{Academic Procrastination Construction}

Procrastination si often associated with the behavior of procrastinating doing or completing tasks. But actually, not all procrastination behavior can be called procrastination. The behavior of delaying starting or completing a new task can be referred to as procrastination if the delaying behavior is done deliberately, uses irrational reasons (such as considering the task too difficult, considering himself unable to complete the task), and has a negative impact on the perpetrator. (Steel \& Klingsieck, 2016)(Klingsieck, 2013)(Zacks \& Hen, 2018).

According to (Tuckman, 1991), procrastination is a habit of unnecessary procrastination, which is carried out by a person because of the fear of failure and the fear of the view that everything must be done and must be completed perfectly, so that individuals 
feel safer not to do it immediately, because of that. will produce something that is not optimal.

Procrastination can occur in various domains of life such as health, family, family activities, work, and academics (Klingsieck, 2013). Procrastination that occurs in the academic field is called academic procrastination. Academic procrastination is the tendency to always or almost always postpone the work of academic tasks and always or almost always experience disturbing anxiety related to academic procrastination that is carried laut (Ferrari, 2010)(Klingsieck, 2013)(Steel \& Klingsieck, 2016).

According to (Tuckman, 1991) academic procrastination includes three components, namely: 1) Tendency to delay or put off doing things (a tendency to waste time in completing tasks that need to be prioritized in order to do other things that are less important); 2) Tendency to have difficulty doing unpleasant things and when possible to avoid or circumvent the unpleasantness (avoiding tasks that are deemed difficult and unwelcome); 3) Tendency to blame others for one's own plight (blaming others for the consequences of procrastinating behavior).

Academic procrastination is mostly done by students, recent research shows that around $70 \%$ of students in tertiary institutions tend to procrastinate regularly (Klingsieck, 2013). Other research even mentions that as many as $80 \%$ of students in tertiary institutions have done academic procrastination (Steel \& Ferrari, 2013). The high level of academic procrastination in students needs serious attention. One of the preventive efforts that can be done is to provide an overview of the effect of academic procrastination on SWB.

\section{Method}

The design of this study was a literature review study. The research data were obtained through library research and hermeneutics. Operationally, researchers conduct literature reviews that come from books and scientific articles. Researchers searched for scientific articles relevant to the research topic through google scholar and sprinter. Scientific articles and books that are relevant to the topic are then analyzed using hermeneutics.

Hermeneutics is used to interpret various relevant literature sources in order to obtain a proper understanding of the existing literature. The use of hermeneutics as a research design makes the interpretation of the literature more critical and reflective. Interpretation becomes more relevant to the phenomenon and the reduction process becomes more complete (Larkin, Eatough, \& Osborn, 2011). Furthermore, the 
researchers conducted a thematic analysis of various existing literature to find important themes related to academic procrastination and SWB.

In order to ensure the validity of the research data, researchers used the triangulation technique by comparing various literature. This technique can minimize data deviation (Heale \& Forbes, 2013).

\section{Result and Discussion}

The policies of the Minister of Education and Culture of the Republic of Indonesia regarding online learning during the Covid-19 pandemic were well responded to by educational institutions in Indonesia. Both formal and non-formal education all used online learning during the Covid-19 pandemic. The media used varies, from WhatsApp, Google Classroom, Zoom Meeting, Google Meet, and other applications (Rosali, Pendidikan, \& Universitas, 2020).

Online learning that suddenly had to be put into effect because of the Covid-19 pandemic certainly had its own impact on learners, including students. Some students reported not being ready to take part in online learning, feeling bored with monotonous learning activities, finding it difficult to understand the subject matter, feeling less able to manage time, feeling less able to regulate themselves in learning, and feeling anxious.

The impact of online learning if not resolved can lead to academic procrastination. Research conducted by ( Jia et al., 2020) on 320 medical students in China showed academic anxiety in research participants during the Covid-19 pandemic. The academic anxiety experienced by the participants also correlated with academic procrastination.

Online learning is prone to academic delays (Akram et al., 2019). Especially if students are not ready for the implementation of online learning. (Ergene \& Türk Kurtça, 2020) research on 314 mathematics course service providers shows a correlation between readiness for online learning and academic procrastination.

There is an increase in academic procrastination behavior during the Covid-19 pandemic, which needs attention. Although there is no definite figure for the increase in academic procrastination in students. Preventive efforts still need to be done. One of them is by describing studies related to the impact of procrastination on happiness.

Existing studies have found a negative impact on academic procrastination behavior. Academic procrastination has been shown to have a negative impact on academic performance. Individuals who do academic procrastination tend to have a lower academic achievement (Kim \& Seo, 2015). Previous research by(Sirois, 2014) has also found a correlation between academic procrastination and stress. Furthermore, according to 
(Sirois, 2014), someone's procrastination is caused by irrational thinking such as seeing a task too difficult, so that it can have an impact on negative moods and stress.

The broader impact of academic procrastination was reported through the study of (Grunschel, Patrzek, \& Fries, 2013). According to this study, academic procrastination has an impact on the following: 1) academic procrastination has an impact on a person's affections such as anger, anxiety, feelings of discomfort, shame, sadness, feeling depressed, feeling dissatisfied, and regret; 2) procrastination has an impact on physical and mental conditions such as fatigue, illness, and sleep disorders; 3) academic procrastination has an impact on academic activities such as piling up work, repeating study requirements, low quality of work, lack of knowledge, negative achievement assessments, and length of the study period; 4) procrastination has an impact on personal life such as finances and interpersonal relationships, and views on the future.

It is very clear that the negative impact of academic procrastination is not only limited to decreasing academic achievement but also has an impact on the emergence of negative feelings and has an impact on life satisfaction which is a component of SWB. This means that the impact of academic procrastination felt by procrastinators will have an impact on SWB. This assumption is reinforced by research by (Krause \& Freund, 2016), as well as research by (Balkis \& Duru, 2016) which found a correlation between academic procrastination and the affective component of SWB. According to this study, the consequences of academic procrastination behavior affect the negative feelings of the perpetrator, which in turn affects SWB.

Previously, (Assur, 2003) research which examined 173 students also produced a conclusion, students who had high academic procrastination scores tended to have low instructors on positive feelings and had a high influence on negative feelings and had an impact on low life satisfaction. the results also showed an increase in negative feelings two days before the exam. This means that when someone delays a task, negative feelings will continue to increase when the deadline for completing the task is closed. Failure to make a decision or hesitation in making a decision will have an impact on regret and low life satisfaction (Tibbett \& Ferrari, 2015).

Evidence that academic procrastination and SWB are correlated constructs is evidenced Bay (Lai \& Lin, 2018). The study examined 321 underdeveloped children in rural areas to get a picture of the relationship between SWB and academic procrastination. The results show that SWB can predict the academic procrastination of children who are lagging behind. Positive or negative feelings and life satisfaction of children living in rural areas can influence academic procrastination. 
SWB is often associated with life goals. Life goals have an important role in someone's SWB, people who have life goals tend to be more satisfied with their lives. When a person can achieve the expected goals, he will experience an increase in SWB. The problem is that procrastination often makes people procrastinate in achieving the goals that have been set so that the SWB is low (Kaftan \& Freund, 2018). Then the focus on the process of pursuing goals can reduce academic procrastination (Krause \& Freund, 2014).

Although it is clear that personality factors have a stronger and more persistent influence on SWB. However, the factors of life events must also be a concern. Many studies have shown that life events such as marriage, getting gifts, being left behind by loved ones, etc. have been shown to have an influence on SWB.

The results of this literature review have also found several recent studies that show a correlation between academic procrastination and SWB. The negative impact of academic procrastination, such as low academic achievement, fatigue, illness, the threat of not graduating, feeling anxious, angry, afraid, doing behavior that violates norms such as cheating, and problems in interpersonal relationships, have been shown to have an effect on SWB. Several existing studies have shown a strong correlation between academic procrastination and the negative feeling component of SWB and have been shown to have a correlation with the life satisfaction component of SWB.

The existence of a very clear influence between academic procrastination and SWB needs the attention of various parties. Experimental studies to find the right strategy to reduce academic procrastination need to be increased.

\section{Acknowledge, Funding \& Ethics Policies}

Thanks to Prof. Dr. Fattah Hanurawan, M.Ed., Dr. Hetti Rahmawati, M.Si., Dr. Nur Eva, M.Psi., Dr. Endang Prastuti, M.Si, who has provided many insights to the author. This research is not tied to funding from any party so it is free of Intertest.

\section{References}

[1] Aghababaei, N. (2018). The Relations among Religiosity, Subjective Well-being, and Attitudes towards Science. International Journal of Behavioral Sciences, 12(2), 6569.

[2] Akram, A., Fu, C., Li, Y., Javed, M. Y., Lin, R., Jiang, Y., \& Tang, Y. (2019). Predicting Students' Academic Procrastination in Blended Learning Course Using Homework 
Submission Data. IEEE Access, 7, 102487-102498. https://doi.org/10.1109/access. 2019.2930867

[3] Ardelt, M., \& Jeste, D. V. (2018). Wisdom and hard times: The ameliorating effect of wisdom on the negative association between adverse life events and well-being. The Journals of Gerontology: Series B, 73(8), 1374-1383.

[4] Argyle, M. (2001). The psychology of happiness. New York: Taylor \& Francis Group.

[5] Assur, A. M. (2003). The relationship of academic procrastination to affective and cognitive

components of subjective well-being. (Doctoral dissertation, ProQuest Information \& Learning).

[6] Balkis, M., \& Duru, E. (2016). Procrastination, self-regulation failure, academic life satisfaction, and affective well-being: Underregulation or misregulation form. European Journal of Psychology of Education, 31(3). https://doi.org/10.1007/s10212015-0266-5

[7] De Neve, J. E., Ward, G., De Keulenaer, F., Van Landeghem, B., Kavetsos, G., \& Norton, M. I. (2018). The asymmetric experience of positive and negative economic growth: Global evidence using subjective well-being data. Review of Economics and Statistics, 100(2), 362-375.

[8] Diener, E. (1984). Subjective well-being. Psychological Bulletin, 95(3), 542.

[9] Diener, E., Tay, L., \& Oishi, S. (2013). Rising income and the subjective well-being of nations. Journal of Personality and Social Psychology, 104(2), 267.

[10] Ergene, Ö., \& Türk Kurtça, T. (2020). Pre-Service Mathematics Teachers' Levels of Academic Procrastination and Online Learning Readiness. Malaysian Online Journal of Educational Technology, 8(4), 52-66. https://doi.org/10.17220/mojet.2020.04. 006

[11] Ferrari, J. R. (2010). Still procrastinating: The no-regrets guide to getting it done. New York: Wiley.

[12] Froh, J. J., Bono, G., \& Emmons, R. A. (2010). Being grateful is beyond good manners: Gratitude and motivation to contribute to society among early adolescents. Motivation Emotion, 34, 144-157.

[13] Galiani, S., Gertler, P. J., \& Undurraga, R. (2018). The half-life of happiness: Hedonic adaptation in the subjective well-being of poor slum dwellers to the satisfaction of basic housing needs. Journal of the European Economic Association, 16(4), 11891233. 
[14] Goodman, F. R., Disabato, D. J., Kashdan, T. B., \& Kauffman, S. B. (2018). Measuring well-being: A comparison of subjective well-being and PERMA. The Journal of Positive Psychology, 13(4), 321-332.

[15] Grunschel, C., Patrzek, J., \& Fries, S. (2013). Exploring reasons and consequences of academic procrastination: An interview study. European Journal of Psychology of Education, 28(3), 841-861. https://doi.org/10.1007/s10212-012-0143-4

[16] Heale, R., \& Forbes, D. (2013). Understanding triangulation in research. Evid Based Nurs, 16(4), 98. https://doi.org/10.1136/eb-2013-101494

[17] Huda, M. J. N. (2015). Perbandingan Prokrastinasi Akademik Menurut Pilahan Jenis Kelamin Di Uin Sunan Kalijaga Yogyakarta. 8(2), 423-438.

[18] Jia, J., Jiang, Q., \& Lin, X. H. (2020). Academic anxiety and self-handicapping among medical students during the COVID-19 pandemic: A moderated mediation model. Research Square, 1-22.

[19] Kaftan, O. J., \& Freund, A. M. (2018). The Way is the Goal: The Role of Goal Focus for Successful Goal Pursuit and Subjective Well-Being. In: Diener, E; Oishi, S; Tay, L. Handbook of well-being. Salt Lake City, UT: DEF Publishers, online.

[20] Kemenkes. (2020). Pedoman pencegahan dan pengendalian coronavirus disease (COVID-19). Retrieved from https://covid19.go.id/p/protokol/pedoman-pencegahandan-pengendalian-coronavirus-disease-covid-19-revisi-ke-5

[21] Kim, K. R., \& Seo, E. H. (2015). The relationship between procrastination and academic performance: A meta-analysis. Personality and Individual Differences, 82, 26-33. https://doi.org/10.1016/j.paid.2015.02.038

[22] Klingsieck, K. B. (2013). Procrastination in Different Life-Domains: Is Procrastination Domain Specific? Current Psychology, 32(2), 175-185. https://doi.org/10.1007/s12144013-9171-8

[23] Krause, K., \& Freund, A. M. (2014). Delay or procrastination-A comparison of selfreport and behavioral measures of procrastination and their impact on affective wellbeing. Personality and Individual Differences, 63, 75-80. https://doi.org/10.1016/j. paid.2014.01.050

[24] Krause, K., \& Freund, A. M. (2016). It's in the means: Process focus helps against procrastination in the academic context. Motivation and Emotion, 4O(3). https://doi. org/10.1007/s11031-016-9541-2

[25] Kushlev, K., Heintzelman, S. J., Oishi, S., \& Diener, E. (2018). The declining marginal utility of social time for subjective well-being. Journal of Research in Personality, 74, 124-140. 
[26] Lai, Y. C., \& Lin, W. Q. (2018). Relations among Perceived Social Support, Subjective Well-being and Academic Procrastination of Rural Left-behind Children. Journal of Shaanxi Xueqian Normal University, 5(6).

[27] Lampropoulou, A. (2018). Personality, school, and family: What is their role in adolescents' subjective well-being. Journal of Adolescence, 67, 12-21.

[28] Larkin, M., Eatough, V., \& Osborn, M. (2011). Interpretative phenomenological analysis and embodied, active, situated cognition. Theory \& Psychology, 1-20. https://doi.org/ $10.1177 / 0959354310377544$

[29] Liu, H. H., Peng, F., Zeng, X. H., Zhao, J. B., \& Zhang, X. Y. (2019). Authoritarian personality and subjective well-being in Chinese college students: The moderation effect of the organizational culture context. Personality and Individual Differences, 138, 79-83.

[30] Lucas, R. E., \& Diener, E. (2015). Personality and subjective well-being: Current issues and controversies. In M. Mikulincer, P. R. Shaver, M. L. Cooper, \& R. J. Larsen (Eds.), APA handbooks in psychology ${ }^{\circledR}$. APA handbook of personality and social psychology, Vol. 4. Personality processes and individual differences (p. 577-599). American Psychological Association. https://doi.org/10.1037/14343-026

[31] Mogilner, C., Whillans, A., \& Norton, M. I. (2018). Time, money, and subjective wellbeing. Handbook of Well-Being. Noba Scholar Handbook series: Subjective wellbeing. Salt Lake City, UT: DEF publishers. Retrieved from nobascholar. com.

[32] Myers, D. G. (2004). Social Psychology. New York. Mc Graw-Hill.

[33] Ningtyas, L. K. S., Tentama, F., \& Situmorang, N. Z. (2018). Gambaran Subjective WellBeing Pada Perempuan Lanjut Usia. The 8th University Research Colloqium 2018" Pengembangan Sumber Daya Menuju Masyarakat Madani Berkearifan Lokal". Universitas Muhammadiyah Purwokerto.

[34] Pavot, W., \& Diener, E. (2011). Personality and happiness: Predicting the experience of subjective well-being. The Wiley-Blackwell Handbook of Individual Differences, 699-717. USA. A John Wiley \& Sons, Ltd., Publication.

[35] Peterson, C., \& Seligman, M. E. P. (2004). Character strengths and virtues: A handbook and classification. Oxford University Press.

[36] Prastuti, E. (2019). Model kesejahteraan subjektif ibu dewasa muda ditinjau dari regulasi emosi, mindfulness dan rasa syukur. Doctoral dissertation, Universitas Airlangga.

[37] Rosali, E. S., Pendidikan, J., \& Universitas, G. (2020). Aktifitas Pembelajaran Daring Pada Masa Pandemi Covid-19 Di Jurusan Pendidikan Geografi Universitas Siliwangi Tasikmalaya. Geography Science Education Journal (GEOSEE, 1(1), 21-30. 
[38] Ruch, W., Wagner, L., \& Heintz, S. (2018). Humor, the PEN model of personality, and subjective well-being: Support for differential relationships with eight comic styles. RISU, 1(1), 31-44.

[39] Ryff, C. D. (1989). Happiness is everything, or is it? Explorations on the meaning of psychological well-being. Journal of Personality and Social Psychology, 57(6), 1069-1081. https://doi.org/doi:http://dx.doi.org/10.1037/0022-3514.57.6.1069

[40] Ryff, C. D., \& Keyes, C. L. (1995). The structure of psychological well-being revisited. Journal of Personality and Social Psychology, 69, 719-727.

[41] Seligman, M. (2018). PERMA and the building blocks of well-being. The Journal of Positive Psychology, 13(4), 333-335.

[42] Sirois, F. M. (2014). Procrastination and stress: Exploring the role of self-compassion. Self and Identity, 13(2), 128-145.

[43] Steel, P., \& Ferrari, J. (2013). Sex, education and procrastination: An epidemiological study of procrastinators' characteristics from a global sample. European Journal of Personality, 27(1), 51-58.

[44] Steel, P., \& Klingsieck, K. B. (2016). Academic Procrastination: Psychological Antecedents Revisited. Australian Psychologist, 51(1), 36-46. https://doi.org/10.1111/ ap.12173

[45] Tibbett, T. P., \& Ferrari, J. R. (2015). The portrait of the procrastinator: Risk factors and results of an indecisive personality. Personality and Individual Differences, 82. https://doi.org/10.1016/j.paid.2015.03.014

[46] Tuckman, B. W. (1991). The development and concurrent validity of the procrastination scale. Educational and Psychological Measurement, 51(2), 473-480.

[47] WHO. (2020). Statement on the second meeting of the International Health Regulations (2005) Emergency Committee regarding the outbreak of novel coronavirus (2019-nCoV). Retrieved from https://www.who.int/news/item/30-012020-statement-on-the-second-meeting-of-the-international-health-regulations(2005)-emergency-committee-regarding-the-outbreak-of-novel-coronavirus-(2019ncov)

[48] Zacks, S., \& Hen, M. (2018). Academic interventions for academic procrastination: A review of the literature. Journal of Prevention and Intervention in the Community, 46(2), 117-130. https://doi.org/10.1080/10852352.2016.1198154 